\title{
歯肉縁下プラークの形成に関する研究
}

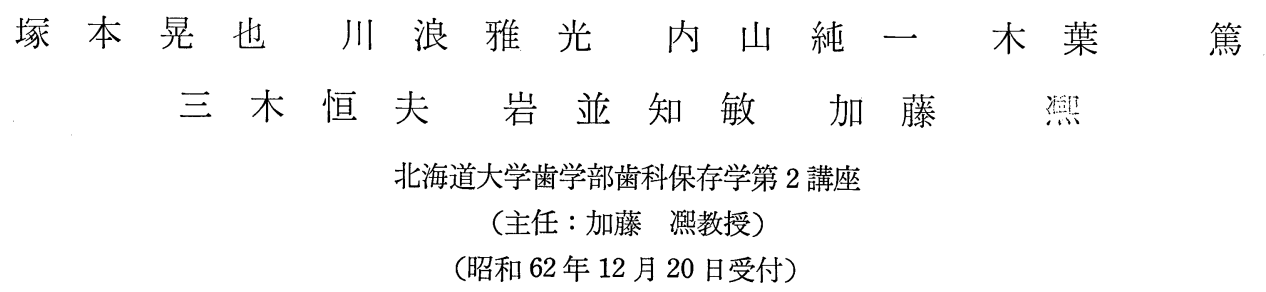

\section{A Study of Subgingival Plaque Formation}

\author{
Kohya TSUKAMOTO, Masamitsu KAWANAMI, Junichi UCHIYAMA, Atsushi KIBA, \\ Tsuneo MIKI, Tomotoshi IWANAMI and Hiroshi KATOH \\ Department of Periodontology and Endodontology, School of Dentistry, Hokkaido University
}

(Chief : Prof. Hiroshi KATOH)

The purpose of this study was to investigate the mode of subgingival plaque formation and its association with various microflora in the thoroughly debrided periodontal pocket by scanning electronmicroscopy. Eleven Periodontally involved teeth with an avarage pocket depth of $6 \mathrm{~mm}$, were selected. Experimental surfaces were thoroughly debrided by flap operation at the baseline. Mechanical plaque control with toothbrush was maintained for 6 weeks after the operation. Then the teeth were extracted and examined by Scanning electronmicroscopy.

The following results were obtained: Subgingival

\begin{abstract}
plaque was formed as the continuation from supragingival plaque. No isolated plaque were recognized in the subgingival area. Average distance of formed subgingival plaque from gingival margin was 0.35 $\mathrm{mm}$ at bucco-proximal site, $0.67 \mathrm{~mm}$ mid-proximally and $0.65 \mathrm{~mm}$ lingua-proximally. The microflora of the plaque composed of coccoids and rods predominantly, but spirochetes were seldom observed. The present study suggests that supragingival plaque is intimately ralated in the formation of subgingival plaque.
\end{abstract}

Key words : Subgingival plaque, Flap operation, Subgingival root surface, Plaque control, Scanning electron microscope.

要旨 : 本実験の目的は, 歯周ポケット内への歯肉縁下プラークの形成のプロセスや細菌丵を検 索することである。 被験歯はポケットの平均が $6.0 \mathrm{~mm}$ の抜去予定の歯周炎罹患歯 11 歯とし, 実験開始時にフラップ手術を行ない, 根 面を徹底的に清掃しプラークフリーの状態とした。被験者にはブラッシングを行なわせ, 手術後 6 週に抜去し, SEM を用いて観察した。

その結果, 縁下プラークは縁上プラークから連続して形成され，歯肉縁下に孤立して形成されているものはなかっ た。縁下プラークの根尖方向への形成程度は, 平均で隣接面の煩側 $0.35 \mathrm{~mm}$, 中央部 $0.67 \mathrm{~mm}$, 舌側 $0.65 \mathrm{~mm}$ であ

り, 隣接面中央部と舌側は比較的大きな值を示した。縁下プラークの細菌叢は, 球菌や桿菌が主体をなし, スピロへ ータはほとんど認められなかった。

今回の観察結果より, 縁下プラークの形成の抑制には, 縁上プラークのコントロールが重要であると考えられた。

本論文の要旨は, 第 28 回春季日本歯周病学会総会（1985 年 6 月 6 日）において発表した。 
索引用語 : 歯肉縁下プラーク, フラップ手術, 歯肉縁下根面, プラークコントロール, 走査型電子顕微鏡

\section{緒言}

慢性辺縁性歯周炎の主な原因はデンタルプラークであ り，プラーク中の各種の微生物特に，グラム陰性嫌気性 桿菌やその代謝産物が歯周組織に為害性をもたらすこと は広く認められている1)。デンタルプラークは臨床的に 歯肉縁上と縁下に分けられるが，特に縁下プラークは歯 周ポケット上皮に直接接して, 歯肉の炎症を増悪し, 付 着機構の破壊, 歯周ポケットの深化, そして歯槽骨吸収 を引き起こす直接的な原因と考えられている。

この縁下プラークをスケーリングや，ルートプレーニ ング等の歯周治療により徹底的に除去すると, 歯周組織 の炎症は改善され健康が回復される。しかし日常臨床で は，治療後メインテナンスが不十分であると，歯周炎の 再発が頻繁にみられる。これは縁下プラークの再形成に よって生ずると考えられている。しかし再形成した縁下 プラークに関して，その中の微生物に対する細菌学的研 究は若干報告 ${ }^{2,3}$ があるものの, 縁下プラークそのものの 再形成プロセスについては，ほとんど知られていない。 特にその形成速度, 形成経路や由来, またポケットの深 さや，歯肉縁上プラークの影響などについては，実験上 の制約もあり,これまでの研究は少ない。これらの問題 を明らかにすることは歯周炎の再発を防止し，良好なメ インテナンスをはかるうえで，臨床上許容できる歯周ポ ケットの深さ, プラークコントロールの程度, リコール 間隔等を決める際に重要な根拠を提供するものと考えら れる。

本教室の紺野 ${ }^{4)}$ は特殊な根面インレーにとりつけた象 牙質薄片を，歯周ポケット内に挿入し，ブラッシングを 行なわせない状態での縁下プラーク形成を，走查型電子 顕微鏡で観察し，歯肉縁下プラークは縁上プラークが根 尖方向に増殖して形成することを報告している。

本実験は日常臨床と同じ状態での縁下プラークの形成 のプロセスを観察する目的で，抜去予定の歯周炎罹患歯 にフラップ手術を行ない, 根面のプラーク，歯石の徹底 的な除去を行なったあと，ブラッシングを行なわせた状 態での縁下プラークの形成程度と, プラーク中の細菌叢 を走査型電子顕微鏡で観察した。さらにオーバーハング 修復物を装着しその影響も併せて観察した。

\section{材料および方法}

\section{1. 実験材料}

被験者は北海道大学歯学部附属病院に来院した患者か ら, 慢性辺縁性歯周炎と診断され, 全身疾患がなく過去 6 力月閒抗生物質の投与を受けていない者 8 名を選ん だ。

被験歯は高度の歯周炎に罹患した抜去予定の歯で隣接 面に $4 \mathrm{~mm}$ 以上の梁い歯周ポケットが存在し，歯肉縁下 に及ぶ修復物がない，前歯 7 本，小臼歯 2 本，下顎大臼 歯 2 本の合計 11 本とした。

被験歯面は前歯と小臼歯は近心隣接面と遠心隣接面, 下顎大臼歯は近心隣接面のみとし，合計 20 歯面とした (表 1)。

表 1 被験歯の内訳

\begin{tabular}{|c|c|c|}
\hline & 被 験 歯 & 被験歯面 \\
\hline 前 歯 & 7 & 14 \\
\hline 小 臼 歯 & 2 & 4 \\
\hline 下顎大臼歯 & 2 & 2 \\
\hline 計 & 11 & 20 \\
\hline
\end{tabular}

\section{2. 実験方法}

実験経過は, 図 1 に示すように被験者には口腔清掃を 指導し，十分に清掃できるようになってから実験開始時 の臨床診査を行ない, フラップ手術を行なって歯肉縁下 付着物を完全に除去した。術後 6 週間を歯肉縁下プラー ク形成期間とし， $2 ， 4 ， 6$ 週に臨床診查を行ない，術 後 6 週に被験歯を抜去して走査型電子顕微鏡にて根面の プラークを観察した。

尚，被験歯面を $\mathrm{A}$ 群と B 群の 2 つに分け，A 群 11 歯 面はブラシの毛先が歯肉辺縁に容易に到達することがで きる正常な状態（以下A群と略）とし, B 群 9 歯面はフ ラップ手術前, 被験歯にマージンがオーバーハングの形 態になるような暫間被覆冠 (レジン製テンポラリークラ ウン) を装着 (図 2)，あるいは隣接面にセメントを接着 し, ブラシの毛先が歯肉辺縁に到達しずらい状態（以下 B 群と略）とした。 


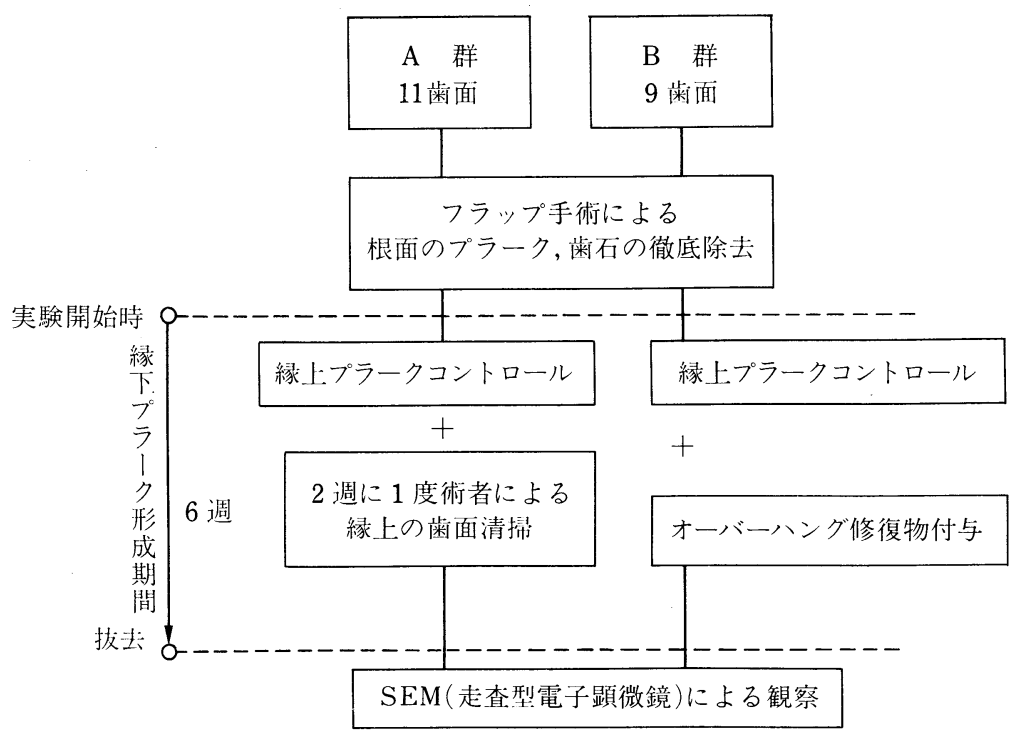

図 1 実験経過

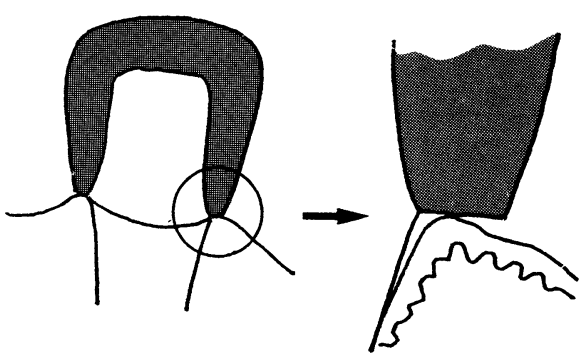

図 2 オーバーハング修復物を装着した状態

1) 臨床診查

全ての被験歯に, 実験開始時, フラップ手術後 2 週, 4 週, 6 週に以下の臨床診查を行なった。

(1) 口腔内カラー写真撮影

(2) 歯垢付着指数 (P1.I.) Silness \& Löe (1964)

Plaque Index を改変して探針による擦過は行なわず， 気銃で歯面を乾燥して肉眼的観察のみで行なった。

(3) 歯肉炎症指数 (G.I.) Löe \& Silness (1967)

Gingival Index を用いて被験歯の歯肉の炎症状態を 評価した。

(4) 歯周ポケットの深さ

$\mathrm{H}-\mathrm{F}$ 社製ポケットプローベ $\mathrm{CP}-11$ を用い $1 \mathrm{~mm}$ 単位 で測定した。

(2)(3)(4) の測定部位は煩舌側各 2 力所とした。尚, ポ ケットの測定は実験開始時と術後 6 週の抜去前のみ測定 した。.
2) フラップ手術

実験開始時に, フラップ手術を行ない歯肉縁下根面に プラークや歯石がまったく認められない状態まで徹底的 に除去した。術後に深いポケットが残存するように, 内 縁上皮や肉芽組織の除去は行なわず, 歯肉弁の縫合は可 及的に術前の高さで行なった。

術後の感染予防のため, 手術の 1 日前から術後 2 日間 のみ抗生物質を投与した。術後 1 週でパックを除去し抜 糸した。

3）歯肉縁下プラーク形成期間

フラップ手術後, 被験歯が抜去されるまでの 6 週間を 歯肉縁下プラーク形成期間とした。

被験者には縁上プラークを取除くため日常行なってい るブラッシングを励行してもらい, A 群では 2 週に 1 度 術者による縁上の歯面清掃を行ない, B 群では歯面清掃 は行なわなかった。

尚, 補助的清掃器具である歯間ブラシ, デンタルフロ スは歯肉縁下に到達する可能性が強いため5) 使用は避け た。

4）被験歯の抜去

フラップ手術後 6 週目に, 浸潤麻酔を行ない被験歯隣 接面の煩側および舌側寄りの偶角付近に歯肉辺縁の位置 を記録するため，エアータービンでノッチを付与した。 縁上, 縁下のプラークの連続性を観察するため隣接面中 央部にはノッチを付与しなかったが, 煩舌側のノッチを 結んだ仮想線が歯肉辺縁の高さを表わすようにした。抜 


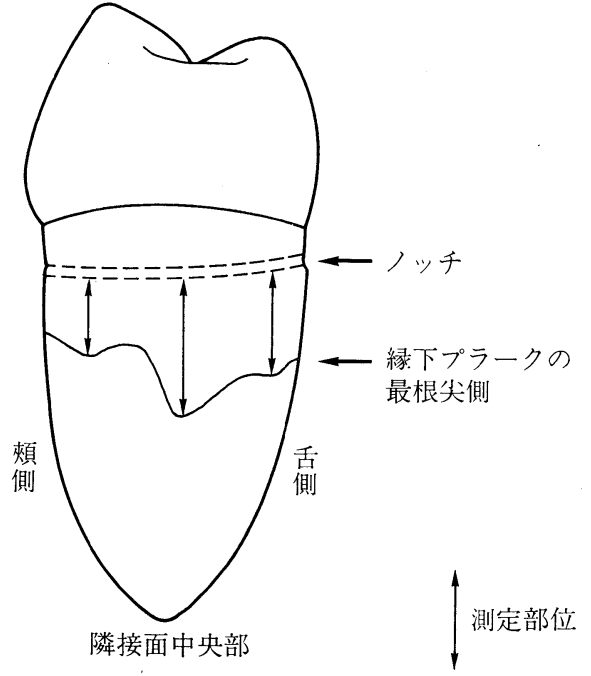

図 3 縁下プラークの形成程度の測定

去は被験歯面に接触しないよう十分に注意して鉗子を用 いて行なった。

5）走査型電子顕微鏡による観察

抜去した被験歯はただちにカコジル酸緩衝液で洗浄, カルノフスキー固定液で 24 時間固定後, ダイヤモンド ディスクにて抜去歯を近遠心的に分割し，その後エタ， 一ル脱水, 酢酸イソアミルを媒体とし臨界点乾燥, スパ ッタリング金蒸着を行ない, 走査型電子顕微鏡にて加速 電圧 $25 \mathrm{kV}$ 作動距離 $25 \mathrm{~mm}$ で根面のプラークを観察し た。

縁上プラークと縁下プラークの連続性及び，縁下プラ ークの根尖方向への形成程度は電顕写真上でノギスを用 いて測定した。歯肉辺縁の位置からプラークの最根尖部 までの距離を隣接面煩側, 隣接面中央部, 隣接面舌側の 3 つの部位で測定した (図 3)。又，歯肉縁下や縁上に形成 されたプラーク中の細菌叢についても詳細に観察した。

\section{結 果}

\section{1. 臨床診査の結果}

A 群と B 群における, P1.I., G.I., の経時的変化を図 4 と図 5 に示した。実験期間中両者間の差は少なかった が, P1.I. の平均值は 6 週でのみ B 群の方が $\mathrm{A}$ 群よりも大 きい值を示した。

煩側と舌側における, P1.I., G.I. の変化を図 6 と図 7 に示した。両者を比較すると, P1.I., G.I. の経時的変化 には差が認められなかった。

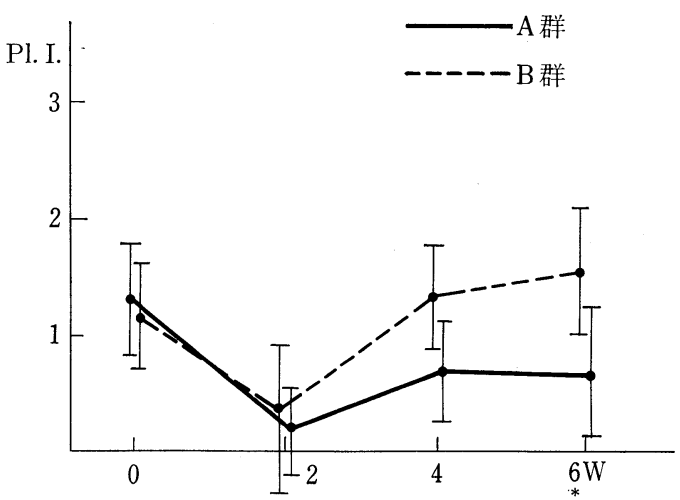

A 群 vs B 群

$* \mathrm{P}<0.05$

図 4 A 群，B 群における P1. I. の経時的変化 $6 \mathrm{~W} A$ vs $B(p<0.05)$

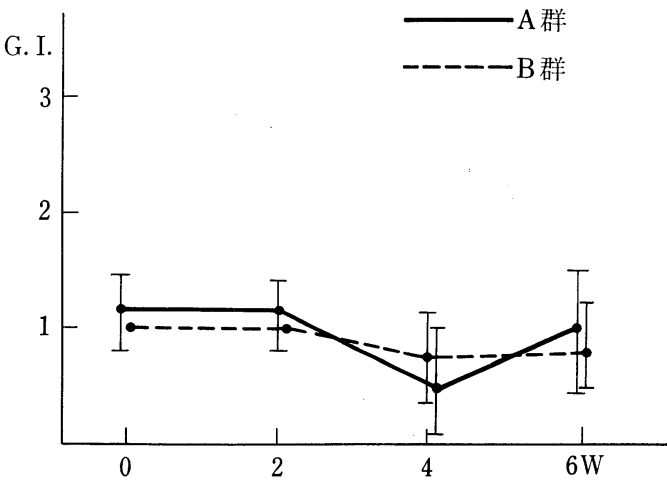

A群 vs B群 (N.S.)

図 5 A 群，B 群における G.I. の経時的変化

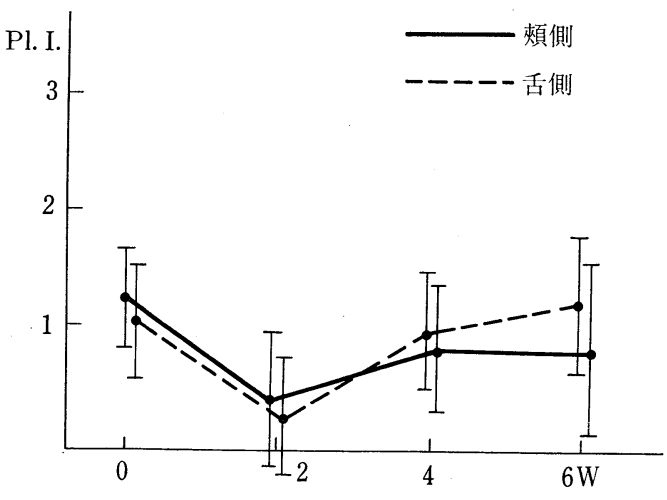

頓側 vs 舌側 (N.S.)

図 6 頰側, 舌側における P1. I. の経時的変化 


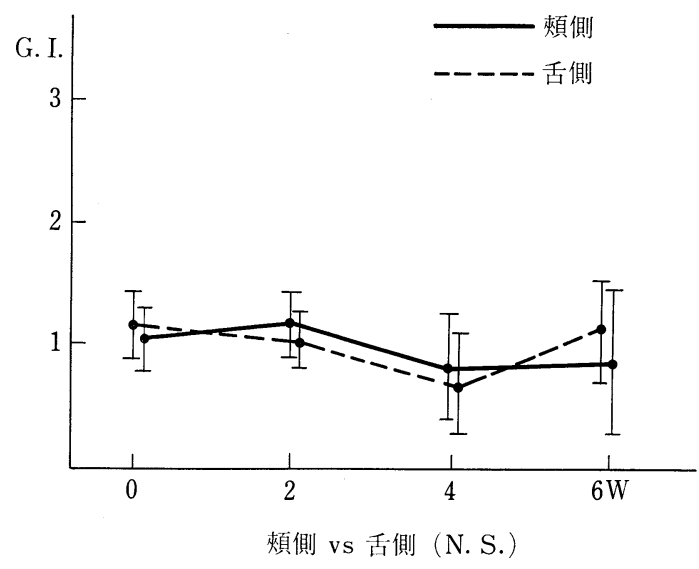

図 7 煩側, 舌側における G.I. の経時的変化

表 2 歯周ポケットの深さの変化 $(\mathrm{mm})$

\begin{tabular}{cc|c|c}
\hline & & 手術前 & 抜去前 \\
\hline $\mathrm{A}$ & 群 & $6.9 \pm 2.0$ & $4.5 \pm 1.9$ \\
\hline $\mathrm{B}$ 群 & $5.2 \pm 1.6$ & $3.1 \pm 2.0$ \\
\hline 煩 側 & $6.3 \pm 2.1$ & $3.4 \pm 2.1$ \\
\hline 舌 側 & $6.0 \pm 2.0$ & $4.0 \pm 2.2$ \\
\hline
\end{tabular}

フラップ手術前と抜去前の歯周ポケットの深さを表 2 に示した。ポケットの深さは， 6 週後にはA群，B 群と もに約 $2.0 \mathrm{~mm}$ 減少した。煩側と舌側を比較すると煩側 の方がより浅くなった。

\section{2. 縁上プラークと縁下プラークの連続性}

電顕写真上で縁上プラークと縁下プラークの連続性を 観察した結果，歯肉縁下にプラークが形成された被験歯 面では，プラークはすべて縁上から縁下に連続して形成 されていた (図 8)。すなわち, 歯肉縁下プラークは縁上 プラークが存在する部位にのみ観察され, 縁上プラーク が存在せずに縁下プラークが形成されている所見は 1 例 も認められなかった。

\section{3. 縁下プラークの形成程度}

縁下プラークの根尖方向の形成程度を部位別に測定し た結果を表 3 に示した。A 群と B 群を比較すると，いず れの部位でも差は認められなかった。

部位別に比較すると，隣接面中央部では平均と最大 值が $0.67 \mathrm{~mm}, 2.65 \mathrm{~mm}$ であり, 舌側では $0.65 \mathrm{~mm}$, $2.11 \mathrm{~mm}$, 煩側は中央部や舌側に比べて少なく, 0.35 $\mathrm{mm}, 1.3 \mathrm{~mm}$ であった。

フラップ手術 6 週後のポケットの深さと縁下プラーク の形成程度との関係を表 4 に示した。プラークの形成程

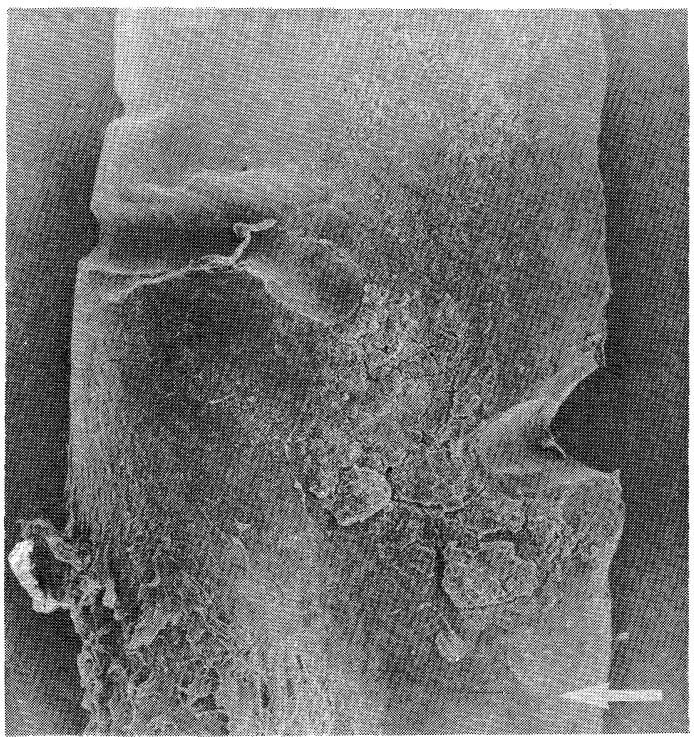

図 8 プラークの連続性を示す SEM 像 (100 倍), 被験歯は 2 遠心隣接面, 縁下プラークは舌側 で歯肉縁下に $1.2 \mathrm{~mm}$ 形成している。（矢印 はプラークの最根尖側縁)

表 3 縁下プラークの形成程度

\begin{tabular}{c|c|c|c}
\hline & 煩側より & 中 央 部 & 舌側より \\
\hline $\mathrm{A}$ 群の平均 & 0.37 & 0.69 & 0.62 \\
\hline $\mathrm{B}$ 群の平均 & 0.33 & 0.55 & 0.45 \\
\hline $\mathrm{Max}$ & 1.30 & 2.65 & 2.11 \\
\hline $\mathrm{Min}$ & 0 & 0 & 0 \\
\hline 平 均 & $0.35 \pm 0.38$ & $0.67 \pm 0.65$ & $0.65 \pm 0.57$ \\
\hline \multicolumn{4}{|c}{} \\
\hline
\end{tabular}

表 4 ポケットの深さによるプラークの形成程度

\begin{tabular}{c|c|c}
\hline & $\begin{array}{c}4 \mathrm{~mm} \text { 以下 } \\
(22 \text { 部位 })\end{array}$ & $\begin{array}{c}5 \mathrm{~mm} \text { 以上 } \\
(10 \text { 部位 })\end{array}$ \\
\hline $\begin{array}{c}\text { 縁下プラーク } \\
\text { の形成程度 }\end{array}$ & 0.44 & 0.68 \\
\hline
\end{tabular}

$(\mathrm{mm})$

度はポケットが $5 \mathrm{~mm}$ 以上の方が $4 \mathrm{~mm}$ 以下よりも平均 で $0.2 \mathrm{~mm}$ 多かったが, 統計的に有意差は認められな かった。

尚, プラークの形成が歯肉縁下へまったく認められな かった被験歯面は 3 歯面あった。

\section{4. 縁下プラークの細菌叢}

歯肉縁下に形成されたプラークの細菌叢は, 被験歯間 

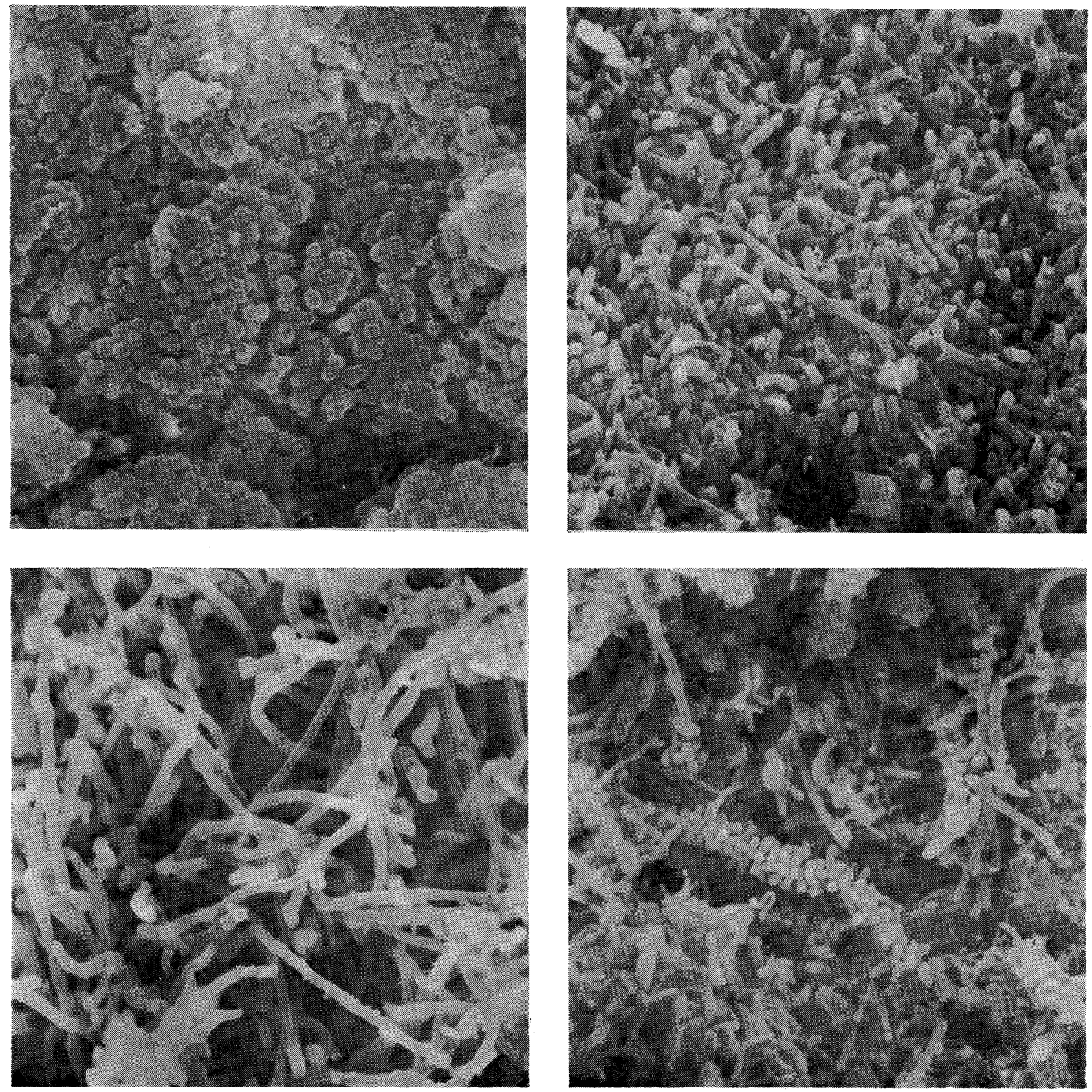

図 $9 \frac{\mathrm{A} \mid \mathrm{B}}{\mathrm{C} \mid \mathrm{D}}$

図 9-A 歯肉辺縁付近のプラーク（3000 倍）出遠心隣接面

図 9-B 歯肉縁下 $0.9 \mathrm{~mm}$ 付近のプラーク (2000 倍) 1 近心隣接面

図 9-C 歯肉縁下 $0.3 \mathrm{~mm}$ 付近のプラーク (2400倍) 6 近心隣接面

図 9-D 歯肉辺縁付近のプラーク (3000 倍) 1 近心隣接面

や又同一歯でも部位によって様々であった。

細菌叢の特徴的な所見として，歯肉辺縁部では球菌が 多数認められ (図 $9 \mathrm{~A}$ ), さらに根尖側では桿菌が歯面に 垂直に配列し, 彎曲した桿菌も認められた(図 $9 \mathrm{~B}$ )。又, 線状微生物も多数存在し，プラークが厚い層を形成して いるものもあった（図 $9 \mathrm{C}$ )。歯肉辺縁付近ではコーンコ ブが 1 例において認められた（図 $9 \mathrm{D}$ )。その他の所見と
して，スピロヘータや鞭毛をもつ微生物はほとんど見ら れず，好中球も少なかった。

一方，縁上プラークは縁下プラークと同様に主に球 菌, 桿菌から構成されており，スピロヘータは全く認め られなかった。 


\section{考察}

歯周組織に為害作用を与える直接的な原因として歯肉 縁下プラークが考えられている。

これまでに, 縁下プラークは歯周病原性を持つ細菌の 存在について, 検討1)されているにもかかわらず，縁下 プラークが形成されるプロセスについての研究はきわめ て少ない4,6,7)。

Waerhaug ${ }^{3)}$ は歯周炎罹患歯に縁上のプラークコント ロールを行なわせた状態で, スケーリングやルートプレ ーニングを行ないその直後, および一定期間後に抜去し，

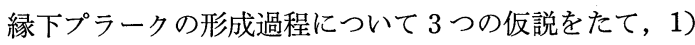
縁上プラークが根尖方向に増殖して縁下プラークは形成 される。2）スケーリングにより縁下プラークが取り残 された所からプラークは再形成する。3）歯肉縁下の根 面に直接細菌が集落を形成し，成熟して縁下プラークが 形成される，と述べている。しかし Waerhaug の研究 は，被験歯の縁下プラークを取り除く方法や抜去までの 期間に統一性がなく，実験方法が十分規格されていない 欠点がある。このようなことから本実験では，被験歯に あらかじめフラップ手術を行ない縁下プラークがまった く認められない状態とし，その後の縁下プラークの形成 程度を観察した。深いポケット内の縁下プラークを完全 に除去した後の縁下プラークの形成程度を知ることは, 臨床上歯周疾患を治療し，メインテナンスしていくうえ で重要な意義をもっていると思われる。

\section{実験方法について}

本実験の目的にそって，深いポケットの歯肉縁下プラ 一クの形成程度を観察するためには, 実験開始時にポケ ットを形成している歯肉縁下の根面に, プラークがまっ たく付着していない状態を作る必要がある。

縁下プラークを除去する方法として Waerhaug ${ }^{3)}$ は， スケーリングとルートプレーニングを行ない，数例にお いてフラップ手術を併用しているが，スケーリングのみ では特にポケット底部においてプラークの取り残しが多 く，歯根表面に陥凹や根吸収があるとスケーラーを頻回 に操作しても完全にプラークを取り除くことができなか っだと述べている。他の研究8,9)でもポケットが深いほ ど, プラークや歯石の取り残しが多いことが報告されて いる。

著者らも本実験に先立ち, 予備実験として深い歯周ポ ケットを有する歯に，スケーリングとルートプレーニン グを行ない抜去して観察したが，プラークの取り残しが
かなり認められた。

本実験では，歯肉縁下にプラークや歯石がまったく付 着していない状態にするため, フラップ手術を行ない直 視下で徹底した根面のデブライドメントを行なった。で きるだけ術前と同じ深さのポケットを形成させるため， 歯肉の内縁上皮汉取除かない上うにした。

尚, 被験歯面を隣接面にしたのは, この部位で歯周ポ ケットが樑いものが多いためである。

縁下プラークの形成期間については, 紺野4)が行なっ た研究において, 実験開始後ブラッシングをさせない状 態としてから 3 週間は縁下プラークの形成が進むが， 3 週以降はほとんど形成されないと報告していることか ら，個体差も考慮に入れて 6 週間とした。

歯肉縁下プラークの形成は, 縁上プラークをコントロ ールする場合と, しない場合とでかなりの差が生じると 考えられている ${ }^{10,11)}$ 。本実験では臨床に近い状態での縁 下プラーク形成のプロセスを知るために, A 群では患者 にブラッシングを指導し, 縁上のプラークコントロール を十分行なわせるとともに, 術者は 2 週に 1 度診查時に 縁上の歯面清掃を行ない， B 群では患者にブラッシング を行なわせたが，オーバーハングしたレジン製暫間クラ ウンを装着し, 縁上プラークが除去されずらい状態にし て, 縁下プラークの形成を観察した。

歯肉縁下に形成されたプラークを観察する方法として は, 実体顕微鏡と走査型電子顕微鏡を使用する方法とが ある。ポケット内に露出した根面全域に怙けるプラーク の形成プロセスは, 被験歯を抜去後トルイジンブルーや クリスタルバイオレット等の組織染色液により根面を染 色し実体顕微鏡を用いて観察することができる ${ }^{12)}$ 。本実 験では縁下プラークの形成プロセスを根面全域にわたっ て観察するだけでなく, 縁下に形成されたプラークに含 まれる微生物を詳細に調べるために, 走查型電子顕微鏡 を用いた。

\section{縁下プラークの形成程度について}

本実験では, Waerhaug ${ }^{3)}$ や紺野 ${ }^{4)}$ の観察と同様に, 縁 下プラークは縁上プラークから根尖方向に連続して形成 されることが観察された。しかし, Waerhaug が観察し たような, 縁上プラークと連続せず縁下に孤立して形成 されたプラークは全く観察されなかった。これは実験開 始時に, フラップ手術を行ない, 縁下プラークを完全に 取り除いたためと考えられる。

縁下プラークの形成程度は, 6 週間で根尖方向に平均 $0.5 \mathrm{~mm}$ 前後であった。これは紺野の 3 週で平均 2.3 $\mathrm{mm}$ 縁下へ侵入 (形成) したという報告と比べるとかな 
り小さな值である。本実験で縁下へのプラークの形成が 少なかった理由としては次の事が考えられる。

1）縁上のプラークコントロールを患者に行なわせて いたため, プラークコントロールを行なわせていなかっ た紺野の場合より, 縁下プラークの源である縁上プラー クの絶対量が少なかった。2) フラップ手術により根面 の有害物質が取り除かれ，しかもプラークコントロール を行なっていたため被験歯の歯肉は炎症が少なく, ポケ ットが浅かった。すなわち，ポケットの深さは手術後平 均 $3.7 \mathrm{~mm}$ となり, 紺野が行なった実験でのポケットの 深さ平均 $6.6 \mathrm{~mm}$ と比べるとかなり浅かった。さらに本 実験では臨床的に健康な歯肉が根面にぴったりと緊張し て密着しており，プラークや外来性の食物残渣が直接歯 肉縁下に入りこみにくかった。3）フラップ手術直後な ので參出液が多く, しかも根面がルートプレーニングに より滑沢になっており，ポケット底部からの滲出液によ り, 細菌などが洗い出されやすかった。4) Waerhaug ${ }^{3)}$ は縁下プラークの形成速度は縁上プラークと比べかなり 遅く, 縁下プラークがスケーリングしたポケット内露出 根面に再形成されるまでには長い時間が必要であると述 べており, 縁下プラークの形成期間として本実験の 6 週 は比較的短時間であった。

今回 6 週以降の観察は行なわなかったが，プラーク形 成期間を長期とした場合, 縁下プラークがさらにどのよ うに形成されるかは，興味ある問題である。

被験歯にオーバーハング修復物を付与し局所の清掃性 を低下させた B 群と，オーバーハングを付与しない自然 な状態の $\mathrm{A}$ 群で, 縁下プラーク形成への影響を調べた が，両群に有意の差は見られなかった。この理由として は次のようなことが考えられる。

本実験では, 患者に口腔清掃を指導しており，P1.I. は 最初の 4 週まで, 有意差がなく, 6 週後に危険率 $5 \%$ で 有意差がみられたが, G.I. は両群間に差は見られなかっ た。このことは患者がブラッシングを熱心に行なってお り， B 群でもオーバーハング修復物のマージン部の歯肉 が歯ブラシにより,よくマッサージされたためと考えら れる。このため B 群も炎症が比較的軽度で, 歯肉線維が よく発達しており歯肉が歯根面に密着していたこと,さ らに両群とも抜去前のポケットの深さの平均が浅くなっ たことから，プラークの根尖方向への形成が抑制された ためと思われる。

縁下プラークの形成程度を隣接面の頖側, 舌側, 中央 部で比較すると, 有意差はなかったが, 頼側は他の部位 に比べ少ない傾向を示した。これは隣接面でも頓側の部
分はブラッシングしやすく, 縁上プラークが除去しやす かったためと考えられる。一方隣接面中央部は最も深く プラークが形成されていた。これはこの部位が歯ブラシ の毛先が到達しにくく, 縁上プラークの除去が困難なこ とが原因と考えられる。今回歯間ブラシとフロスを使用 させなかったため, 隣接面中央部の清掃は困難であり, 早期にプラークが付着し歯肉に炎症が生じ, 縁下プラー クが形成されやすかったものと思われる。

\section{縁下プラークの細菌叢について}

歯肉縁下に形成されたプラークの細菌叢を観察した研 究には, Newman ${ }^{13,14)}$, Saglie ${ }^{15)}$, Listgarten ${ }^{16)}$, Mousques $^{17,18)}$ の報告がある。Newman ${ }^{13)}$ は，歯周炎罹患歯 の縁下プラークを走查型電子顕微鏡を用いて観察し，プ ラークの最根尖側部には, 細菌が単一でコロニーを形成 しているものは存在せず, 線状微生物や桿菌, 球菌が多 く，様々な大きさのスピロヘータも観察している。Sag$1 \mathrm{ie}{ }^{15)}$ も，歯周ポケットの最根尖側部に形成された縁下 プラークの細菌叢を詳細に観察し, 縁下プラークの最根 尖側部では種々の細菌が存在し, スピロヘータは線状微 生物よりもさらに根尖側部に認められたと報告してい る。 Listgarten ${ }^{16)}$ は, 成人型歯周炎では根面に付着し ているプラークには球菌や桿菌が多く, 遊離プラークに は，スピロヘータや彎曲した桿菌が高比率に存在するこ とを報告している。

本実験の観察結果では, 縁下プラークの細菌叢は球菌 や桿菌が多く, 線状微生物も認められた。この点に関し ては Newman, Saglie, Listgaten の所見と同じであっ た。一方スピロヘータは，ほとんど認められなかった。

これまでに，歯周疾患とスピロヘータとの関連につい てはいくつかの研究がある ${ }^{16,19,20)}$ 。川浪 ${ }^{21)}$ は, サルを用 い縁下プラークの形成に関する研究を行ない, 歯肉の炎 症の程度とスピロヘータの存在とに関連があることを観 察している。さらに佃ら ${ }^{22}$ は, 歯周炎の患者にブラッシ ングを行なわせ，ポケット内細菌叢の変化を暗視野顕微 鏡で観察した結果, 炎症が改善するとスピロヘータは有 意に減少したことを報告している。

本実験でスピロヘータがほとんど認められなかった理 由として, 次の 2 つがあげられる。1）実験開始 時に, フラップ手術を行なって歯肉縁下をプラークフリーの状 態にしたため, スピロヘータは存在しなかった。2）実 験開始後も，ブラッシングによる縁上のプラークコント ロールを行なっていたので，縁上プラーク中にはスピロ ヘータが存在しなかった。このことは，6 週後に抜去し て縁上プラークを走査型電子顕微鏡で観察した結果， ス 
ピロヘータが認められなかったことからも確認されてい る。すなわち, 歯肉縁上プラークにスピロヘータが存在 しなかったために, 縁下プラーク中にもスピロヘータは 存在しなかったと思われる。

今回の実験結果より, 平均 $3.7 \mathrm{~mm}$ のポケットでの歯 肉縁下プラークの形成程度は, $0.5 \mathrm{~mm}$ 前後であったこ とから, 臨床的にプラークの形成は少ないと思われる。 これは一度プラークフリーにした深い歯周ポケットで も, 縁上のプラークコントロールを徹底し, 健康な歯肉 が維持されると, 縁下にプラークは再形成されず, 良好 なメインテナンスも可能になるといら示唆を与える。

今後さらに検討を加え, 縁下プラークの形成メカニズ ムについて明らかにしていきたいと思う。

\section{結論}

歯肉縁下プラークの形成のプロセスを明らかにする目 的で, 抜去予定の歯周炎罹患歯 11 歯, 20 歯面にイ二シ ヤルプレパレーション後フラップ手術を行ない, 根面を プラークフリーの状態とし，9歯面にはオーバーハング 修復物を装着して 6 週後に抜去し, SEM を用いて観察 した。その結果次のような結論を得た。

1. 縁上と縁下のプラークにはすべて連続性があり, 縁上プラークが存在せずに縁下プラークが形成されてい る所見は，1例も認められなかった。

2. 部位別縁下プラークの形成程度は, 平均で隣接面 煩側 $0.35 \mathrm{~mm}$, 隣接面中央部 $0.67 \mathrm{~mm}$, 隣接面舌側 0.65 $\mathrm{mm}$ で, 3 者間に有意差はなかったが, 中央部と舌側は 大きい傾向を示した。

3. 縁下プラークの形成程度は, オーバーハング修復 物装着群と非装着群で平均, $0.44 \mathrm{~mm}$ と $0.59 \mathrm{~mm}$ であ り，両群間には有意差はなかった。

4. 縁下に形成されたプラークの細菌叢は, 球菌や桿 菌が主体をなし, 他に線状微生物や彎曲した桿菌も観察 されたが，スピロヘータはほとんど認めれなかった。

以上の結果より, 縁下プラークは縁上プラークから連 続して形成されると考えられ，縁下プラークの形成を抑 えるには縁上プラークのコントロールが重要であると考 えられた。

\section{文献}

1) Slots, J., Mashimo, P., Levine, M.J. and Genco, R.J. : Periodontal therapy in humans. I. Micro- biological and clinical effects of a single course of periodontal scaling and root planing, and of adjunctive tetracycline therapy. J. Periodontol., $50:$ 495-509, 1979.

2) Waerhaug, J. : Healing of dento-epithelial junction following subgingival plaque control. I. As observed in human biopsy material. J. Periodontol., $49: 1-8,1978$.

3) Waerhaug, J. : Healing of dento-epithelial junction following subgingival plaque control. II As observed on extracted teeth. J. Periodontol., $49: 119-134,1978$.

4）紺野純一：歯周炎患者における歯肉縁下プラーク 形成に関する研究一走查型電子顕微鏡による観 察一. 日歯周誌, $25: 300-323,1983$.

5) Waerhaug, J. : The interdental brush and its place in operative and crown and bridge dentistry. J. Oral Rehabilitation., $3: 107-113$, 1976.

6) Waerhaug, J. : Effect of toothbrushing on subgingival plaque formation. J. Periodontol., 52 : 30-34, 1981.

7) Listgarten, M.A., Mayo, H.E. and Tremblay, R. : Development of dental plaque on epoxy resin crowns in man. A light and electron microscopic study. J. Periodontol., $46: 10-26$, 1975.

8) Rabbani, G.M., Ash, M.M. and Caffesse, R.G. : The effectiveness of subgingival scaling and root planing in calculus removal. J. Periodontol., $52:$ 119-124, 1981.

9）松尾良平：スケーリング，ルートプレーニングの 歯肉縁下根面における器具操作の効果について. 日歯周誌, $25: 80-97,1983$.

10) Tabita, P.V., Bissada, N.F. and Maybury, J. E. : Effectiveness of supragingival plaqne control on the development of subgingival plaque and gingival inflammation in patients with moderate pocket depth. J. Periodontol., 52 : 88-93, 1981.

11) Smulow, J.B., Turesky, S.S. and Hill, R.G. : The effect of supragingival plaque removal on anaerobic bacteria in deep periodontal pockets. JADA, 107 : 737-742, 1983. 
12) Waerhaug, J. : A method for evaluation of periodontal problems on extracted teeth. J. Clin. Periodontol., 2 : 160-168, 1975.

13) Newman, H.N. : The apical border of plaque in chronic inflammatory periodontal disease. Brit. dent. J., 141 : 105-113, 1976.

14) Newman, H.N. : The approximal apical border of plaque on children's teeth. I. Morphology, Structure and cell content. J. Periodontol., 50 : 561-567, 1979.

15) Saglie, R. : A scanning electron microscopic study of the relationship between the most apically located subgingival plaque and the epithelial attachment. J. Periodontol., 48 : 105-115, 1977.

16) Listgarten, M.A. : Structure of the microbial flora associated with periodontal health and disease in man. A light and electron microscopic study. J. Periodontol., 47 : 1-18, 1976.

17) Mousques, T, Listgarten, M.A. and Phillips, R.W. : Effect of scaling and root planing on the composition of the human subgingival microbial flora. J. Periodontal Res., 15 : 144-151,
1980.

18) Mousques, T., Listgarten, M.A. and Stoller, N.H. : Effect of sampling on the composition of the human subgingival microbial flora. J. Periodontal Res., 15 : 137-143, 1980.

19) Listgarten, M.A. and Schifter, C. : Differential dark field microscopy of subgingival bacteria as an aid in selecting recall intervals : results after 18 months. J. Clin. Periodontol., 9 : 305316, 1982.

20) Listgarten, M.A. and Levine, S. : Positive correlation between the proportion of subgingival spirochetes and motile bacteria and susceptibility of human subjects to periodontal deterioration. J. Clin. Periodontol., 8 : 122-138, 1981.

21）川浪雅光 : サルの外科的露出根面における歯垢形 成の実験的研究. 日歯周誌, $22: 187-203,1980$.

22）佃 宣和，紺野純一，川浪雅光，内山純一，塚本 晃也, 木葉 篤, 白石ゆかり, 石川 純 : ブラッ シングに伴なう歯周ポケット内細菌叢の変化. 日 歯周誌, $25: 545-553,1983$. 